
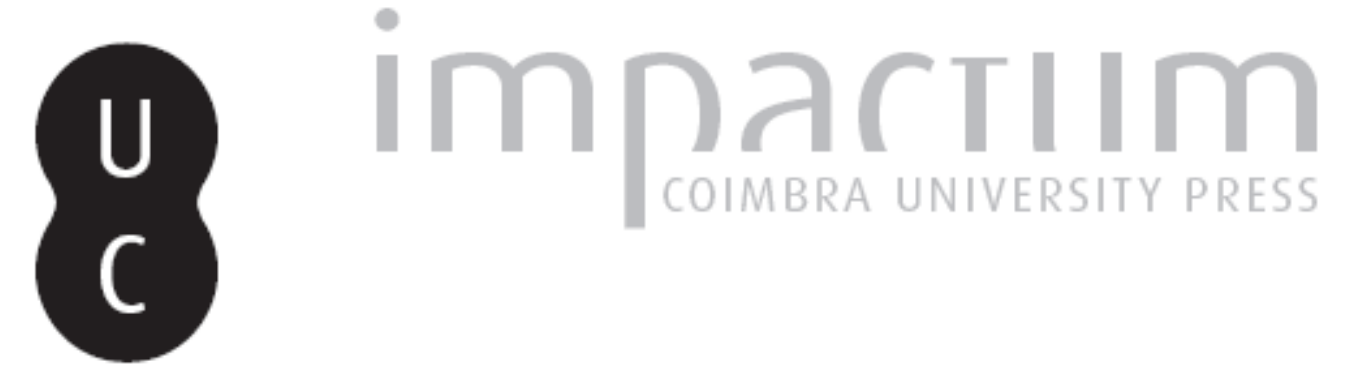

\title{
Plato in Japan: past, present and future
}

\author{
Autor(es): Notomi, Noburu
}

Publicado por: Imprensa da Universidade de Coimbra

URL persistente:

URI:http://hdl.handle.net/10316.2/42280

DOI:

DOl:https://doi.org/10.14195/2183-4105_1_3

Accessed : $\quad$ 26-Apr-2023 15:23:00

A navegação consulta e descarregamento dos títulos inseridos nas Bibliotecas Digitais UC Digitalis, UC Pombalina e UC Impactum, pressupõem a aceitação plena e sem reservas dos Termos e Condições de Uso destas Bibliotecas Digitais, disponíveis em https://digitalis.uc.pt/pt-pt/termos.

Conforme exposto nos referidos Termos e Condições de Uso, o descarregamento de títulos de acesso restrito requer uma licença válida de autorização devendo o utilizador aceder ao(s) documento(s) a partir de um endereço de IP da instituição detentora da supramencionada licença.

Ao utilizador é apenas permitido o descarregamento para uso pessoal, pelo que o emprego do(s) título(s) descarregado(s) para outro fim, designadamente comercial, carece de autorização do respetivo autor ou editor da obra.

Na medida em que todas as obras da UC Digitalis se encontram protegidas pelo Código do Direito de Autor e Direitos Conexos e demais legislação aplicável, toda a cópia, parcial ou total, deste documento, nos casos em que é legalmente admitida, deverá conter ou fazer-se acompanhar por este aviso.

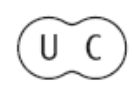




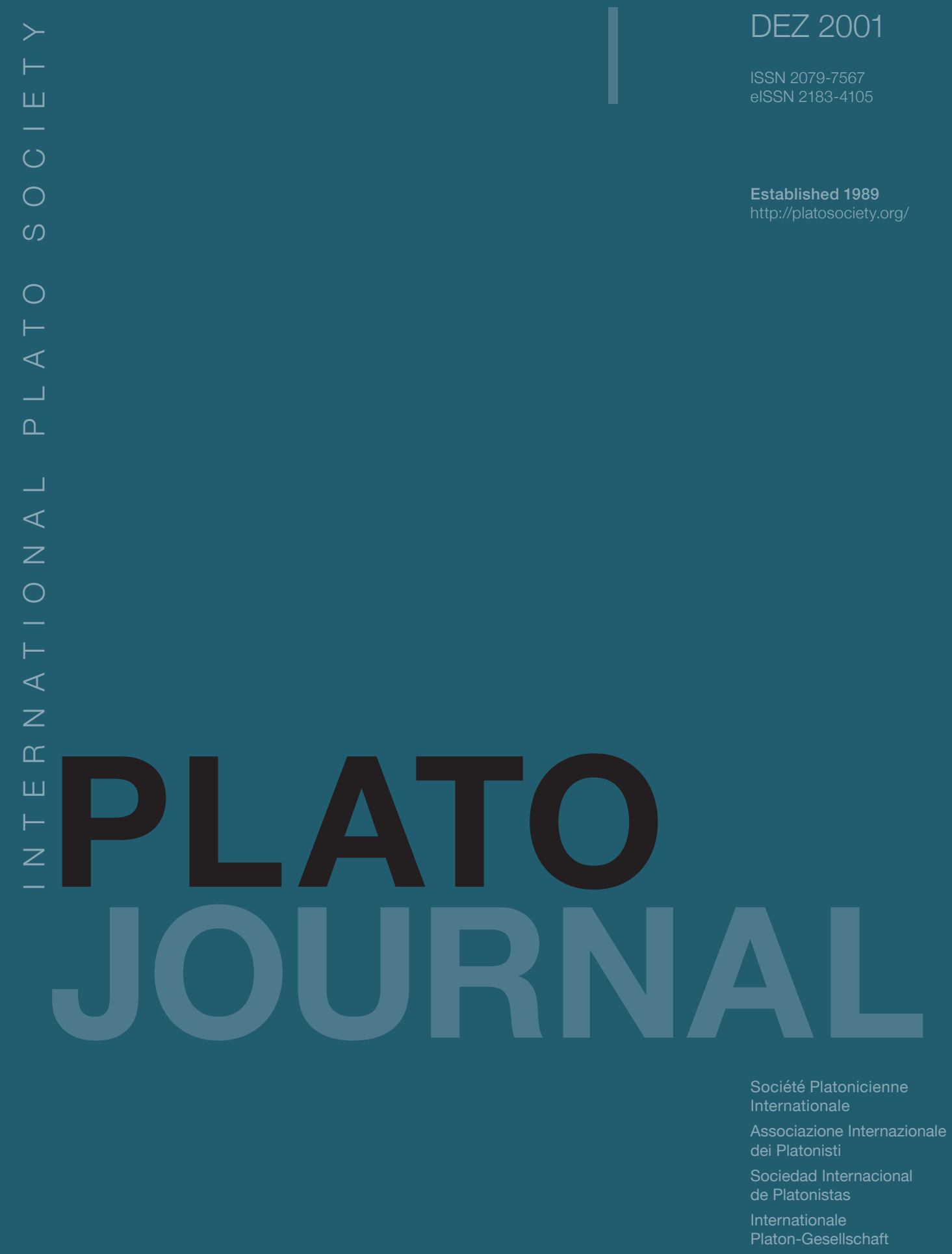




\section{Plato in Japan: Past, Present and Future}

NOTOMI, Noburu, in 1. Plato 1 (2001),

[En ligne], January 2001

\section{Introducing Plato Studies in Japan}

Plato studies in Japan are now becoming better known through the activities of the International Plato Society (IPS) and in other ways, but the real situation is still largely obscure. People outside Japan may wonder why and how we Japanese scholars read Plato. Since Japanese academic circles tend to be closed to the outer world, mainly for linguistic and cultural reasons explained later, I am writing to outline some important features of Plato studies in Japan. However, this is not meant to be simply a factual report. By reflecting on our present situation and its historical background, I shall make some suggestions for the future: what can we Japanese scholars contribute to Plato studies in the world, and what kind of international exchange will advance our understanding of Plato's philosophy?

\section{Present: Scholarly Works Known and Unknown}

Even in the 1980s, Westerners expressed surprise when they learned that over a hundred scholars teach and do research on ancient Greek philosophy in Japanese universities. Owing to the globalisation of the academic world, many Japanese scholars study abroad (mainly in the UK, USA and Germany) and read papers at international conferences every year. Nowadays, there are more occasions for exchanging our views face to face. The IPS, since its foundation in 1989, has been playing a great role in making Japanese academic work on Plato known to the world.

Shinro Kato (Professor Emeritus of Tokyo Metropolitan University) has been an active member of the IPS and was a committee member between 1989 and 1995. He is famous in Japan for his pioneering work on the early dialogues. His book, Plato's Earlier Philosophy, (in Japanese, Tokyo) was published in 1988; one chapter of this was revised for publication in English as 'The Apology: the Beginning of Plato's own Philosophy' (Classical Quarterly NS 41 (1991) 356-64). Instead of treating the early dialogues as pictures or reports of the historical Socrates, Kato sees the essence of Plato's own thinking as present from the beginning, that is, in the Apology. At the IPS Symposia Platonica, Kato has contributed mainly to the discussion of later dialogues. His paper, 'The Role of Paradeigma in the Statesman', appeared in Reading theStatesman: Proceedings of the III Symposium Platonicum (ed. C. J. Rowe, Saint Augustin, 1995, 162-72), and the recent discussion, 'The Crito-Socrates Scenes in theEuthydemus: a Point of View for Reading the Euthydemus', is included in Proceedings of the V Symposium Platonicum (edd. T. M. Robinson and L. Brisson, Saint Augustin, 2000, 123-32). It is especially his efforts that have led younger Japanese scholars (including me) to participate in international academic activities. Following Kato, several scholars have attended the Symposia Platonica and contributed to the debates there. Teruo Mishima, Professor of Aoyama Gakuin University, whose interest lies in ethical issues, examined the last part of the Statesman in 'Courage and Moderation in the Statesman', in Reading the Statesman: Proceedings of the III Symposium Platonicum (ed. C. J. Rowe, Saint Augustin 1995, 306-12). At the last Symposium I discussed the Charmides from the historical, prosopographical, and political viewpoints in 'Critias and the Origin of Plato's Political Philosophy', which is published in Proceedings of the V Symposium Platonicum (edd. T. M. Robinson and L. Brisson, Saint Augustin, 2000, 237-50).

Before the IPS started, several articles by Japanese scholars had already appeared in the major periodicals in English. In 1974, one of the leading Japanese scholars, Norio Fujisawa (Professor Emeritus of Kyoto University) published 'Echein, Metechein and Idioms of 'Paradeigmatism' in Plato's Theory of Forms' (Phronesis 19 (1974), 30-58). His detailed analysis of Plato's terminology shed new light on such controversial issues as the Third Man Argument and the place of the Timaeus in Plato's work. Kunio Watanabe (Professor at Ibaraki University) contributed 'The Theaetetus on Letters and Knowledge' to Phronesis 32 (1987), 143-65, and Yahei Kanayama (Professor at Nagoya University) wrote 'Perceiving, Considering, and Attaining Being (Theaetetus 184-186)' for Oxford Studies in Ancient Philosophy 5 (1987), 29-81. The Theaetetus was most popular in the 1980s among Japanese scholars, inspired by Myles Burnyeat's impressive seminars held in Tokyo and elsewhere in Japan in 1980-1. Unfortunately, these articles are less wellknown than they deserve, perhaps because of the lack of direct contact between their authors and Western readers.

I can add some more works done by Japanese scholars in other journals or proceedings, but the list of the published articles and books (including my own, The Unity of Plato's Sophist: between the Sophist and the Philosopher, Cambridge, 1999) might give an impression that Plato is the sole concern for Japanese scholars of ancient philosophy. Here I must emphasize that this list does not reflect the actual situation in Japan.

First, the number of the books and articles both on Plato and other Greek thinkers published in Japan is far larger. The annual bibliography of the Classical Society of Japan (March, 2000) reports that twenty-five books (including translations) and one hundred 
and fifty articles were published in 1998-9, of which five books and forty-five articles deal with Plato (only a few written in English). The Classical Society of Japan (established in 1950) has 570 members, of which about $40 \%$ are philosophers. The Society of Ancient Philosophy at Kyoto University (Kodai Tetsugakkai, 150 members), the Greek Philosophy Seminar at Tokyo University (90 senior members) and a few other regional societies are active and provide scholars with opportunities for discussion and publication. Tokyo University and Kyoto University, the two most important academic centres, along with several other major universities, train specialists in Greek philosophy, while many Japanese universities and colleges provide opportunities for general education or advanced research in this area. Plato is a prime subject, but as much research has been done on Aristotle. Moreover, the Presocratic thinkers attract many scholars, and interest in Hellenistic philosophy is gradually developing among younger scholars.

Not only the quantity and range, but also the quality of research is probably difficult to imagine solely from publications in English. Apart from Kato's pioneering work on early Plato, Yuji Matsunaga (Professor Emeritus of Kyushu University) produced an excellent translation and analysis of the Phaedo. He is best known for acute and profound examination of the theory of Forms, mainly in the Phaedo and Republic. In his book, Knowing and Not-Knowing: an Introduction to the Study of Plato's Philosophy (Tokyo, 1993), based on a collection of articles written in Japanese from the 1960s to 1980s, Matsunaga approaches the essence of Plato's thinking by focusing on the 'separation' (rather than 'participation') of the Forms from sensibles and from each other. He avoids treating Plato's theory of Forms as a fixed doctrine, and, instead, emphasises the dynamic process of recognising 'things in themselves' as distinct realities out of the phenomenal world of confusion. He sees Plato's inquiry into the Forms as the ultimate response to Socrates' encouragement to care for the soul. Unfortunately his work has not yet been introduced outside Japan. Following these distinguished and innovative scholars, younger generations in Japan are exploring new approaches to Plato.

Western readers may wonder why so many works written in Japan remain unknown elsewhere in the world. I think there are two major cultural factors. First, the effort we need to make to discuss or write in European languages is linguistically more demanding than can easily be imagined. Philosophical argument is by no means straightforward: the language you use implies a particular type of logic and rhetoric and, indeed, a specific way of thinking about the issues themselves. Our traditional way of thinking is alien to such Western ideas as monotheism (e.g. Christianity), formal logic, modern science, democracy and individualism. Also, we have academic communities which are large enough to be self-sufficient, and, consequently, not many scholars find it necessary to make the effort to express their own views in other languages. Although more students and younger scholars have recently gone abroad to be trained (in the UK or the USA), these still remain a minority. Without a common historical background, interest and education, it is not easy to participate in 'international' debate in conferences and journals. It is probably the combination of these reasons that limits the academic activities of Japanese scholars in the international context.

\section{Past: Facing Western Civilisation}

In order to understand the present situation of Plato studies in Japan, we need to place this in a larger historical perspective. Western philosophy was introduced after Japan opened the country to the world in the mid-19th century. While the Meiji government was eager to introduce Western technology and practical branches of learning (law, medicine and natural sciences), more basic and theoretical studies were largely neglected. Some of the Japanese who went abroad to study Western sciences became aware that it was impossible to acquire a full understanding of Western civilisation without knowing its Greek and Roman origins, a point underlined by foreign scholars who were invited to Japan. Dr. Raphael Koeber (a German lecturer in philosophy at Tokyo Imperial University in 1893-1914) emphasised the importance of studying the classics and educated younger students to become pioneers and leaders in this academic field. Since then, research on Western philosophy, especially Greek philosophy as its basis, has been considered essential for higher education and has played a major part in Japanese universities. It is striking that a distinguished Japanese philosopher, Kitaro Nishida (1870-1945) developed his original theories on the basis of his understanding of Greek philosophy as well as of the Chinese and Buddhist heritage.

Plato's works were already translated into Japanese before the Second World War (in the earlier stages from modern European languages and later directly from Greek), but research on Plato developed especially in the post-war period. Michitaro Tanaka (19021985, Kyoto University) led this field of research and translated many major Platonic dialogues. He encouraged classical studies, particularly on Plato, in order to understand the essence of Western civilisation, for example, humanism. He believed that ignorance of this essence had led pre-war Japan to isolationism and fascism and that it had also allowed hasty and uncritical importation of American democracy after the War. Plato was invoked at once as a promoter of Western civilisation and as an antidote to superficial Westernization. Tanaka and his followers (Norio Fujisawa and others) produced a translation of the whole Platonic corpus. Their achievement was the Iwanami edition (1974-1978, a fifteen-volume translation of all the dialogues (genuine and spurious) with a full index, which has become the standard translation.

One characteristic feature of Japanese scholarship is philological scrutiny. We have a long tradition of importing and absorbing other more advanced cultures (Chinese and Indian); the Buddhist and Confucian scholars in the Middle Ages invented and developed a methodology for treating classical Chinese texts as our own. This tradition, in combination with Western philology introduced by Tanaka and others, formed our modern attitude toward the Western classics. This explains why research on Western classical philosophy was developed so quickly and successfully in Japan. Although Japanese students start to learn the Greek language, if they wish, only at universities, those who specialise in Greek philosophy are required to read the original texts with commentaries in 
European languages. The Japanese translations are mostly accurate and reliable, yet priority is still placed on reading the texts in their original language.

On the other hand, modern Japanese scholarship of Western classical philosophy suffers from the same disadvantage as that of our predecessors: the difficulty or impossibility of reading manuscripts at first hand compels us to concentrate on the published editions of classical texts. Probably for this reason, many scholars are reluctant to extend research beyond Plato and Aristotle, the two major philosophers. In general, because of this limitation, we Japanese scholars focus on the interpretation of classical texts.

\section{Future: a Japanese Approach to Plato}

In spite of the surprising development of Plato studies after the Second World War, I think that Plato scholars, inside and outside Japan, now need to think very hard about the future direction of this work.

In the 1990s, not so much original research was achieved in Japan as had been expected, while most scholars occupied themselves in catching up with various new trends imported from Europe and America. In a sense, we have taken part in important debates such as that about the Third Man Argument, the theory of Forms in late Plato particularly the Timaeus, the Socratic elenchus, and the interpretation of the Theaetetus. But these issues were originally raised and discussed by Western scholars, led by G. Vlastos, H. Cherniss, G. E. L. Owen and others. Although Japanese scholars have responded perceptively to each of these issues, it is more rare to find Japanese scholars playing a collaborative role in identifying fresh issues. Moreover, the influence is always one-sided. It goes from the major Western countries to Japan; and our response to this influence does not make much impact on scholarship in those countries.

This lack of mutual communication is partly due to the enclosed character of the Japanese academic world and the linguistic gap explained above. Whereas all Japanese scholars (without exception) read and study works written in European languages (usually English, German, French, and sometimes, Italian), not a single Western scholar has so far read - or even tries to read - the products of Japanese scholarship on Plato and other Greek philosophers in our own language. Our books, articles and book-reviews written in Japanese never encounter serious criticism or reactions from outside Japan; and so we do not have this type of stimulus for our academic discussion. Realistically, we have to accept that the linguistic gap for non-Japanese is hard to bridge, and that our efforts to learn and use European languages such as English will continue to be necessary, indeed urgent. But co-operation is also necessary and profitable not only for Japanese scholarship but also for Westerners. In order to promote academic exchange, we Japanese scholars must make every effort to attract Westerners' interest by the originality of our concerns and approaches to Plato.

My own experience of studying and doing research on Plato in Cambridge has confirmed two basic beliefs: first, reading Plato provides us (people all over the world) with a common basis for discussion on a range of philosophical issues; second, Japanese approaches may raise an important challenge to Western scholarship in the interpretation of Plato.

As noted earlier, the original motivation among Japanese for reading Plato derived from the desire and need to understand Western civilisation, but our concern is not confined to this. Plato appeals to us not just as a distant, though influential, figure, but as a serious thinker speaking directly to us. No doubt, Plato's thought reflects his own age and culture. Nevertheless, the questions he raised about the good life, the soul, the virtues, politics and so on still force us to reflect on our own way of life. Also, we Japanese can look at Plato from a different, and more detached, perspective from those who live within the Platonic tradition. For example, when Matsunaga offers his interpretation of Plato's argument on the immortality of the soul, his reading suggests that we should ask the substantive philosophical question: what is it for our soul - as a real self - to be? The final argument of the Phaedo tries to answer this fundamental question, and Plato's argument is by no means an obsolete dogma or metaphysical theory. How to live well (to eu zên) remains a crucial question, and we must face it as Socrates and Plato did. Thus, reading Plato leads us to do philosophy with a perspective that reaches across time and space.

Also, the Japanese viewpoint leads us to reconsider what 'philosophy' means. 'Philosophy' (philosophia) is said to have begun in ancient Greece, and Plato was one of its originators. We need to recognise that 'philosophy' is a particularly Western or Greek way of thinking, and so we Japanese, who live outside this tradition, need to use our reading of Plato to ask the true meaning of 'philosophy' (see the Preface of my book, The Unity of Plato's Sophist, Cambridge 1999). It is only by clarifying the potential and limitations of what 'philosophy' means, in the Platonic tradition, that we can truly appreciate philosophy as a universal human pursuit that transcends its Greek or Western origins.

My monograph on the Sophist intended to locate in this broad but essential context the question raised by Plato in that dialogue. I suggested that his priority was to investigate the fundamental question, 'what is the sophist?', and by answering it, to secure the possibility of philosophy and to show what this means. This question regarding the sophist has scarcely been raised by Western scholars, probably because they have taken Plato's 'philosophy' for granted and, instead, focused on many difficult 'philosophical' problems, which have been hotly debated in the long tradition of Western scholarship. But I believe Plato is a living philosopher primarily because he never stops asking fundamental questions about the nature and possibility of philosophy, and invites us to engage in the same quest.

For Western people, Plato is, obviously, a great cultural ancestor, and reading Greek philosophy may be a matter of course. In contrast, people outside Europe and America, such as Japanese, Korean, Chinese, Indian, Arab and African, always confront a serious 
and fundamental question about why we should read Plato. However, the very fact of having to ask this question and to approach Plato from an alien standpoint can give a new dimension to our reading of Plato and our practice of philosophy. To widen our perspective and to raise fresh questions, we need pluralistic co-operation in Plato studies. For this purpose, an international meeting such as a Pan-Pacific Plato Forum (embracing Japan, Korea, China, Australia, the West Coast of the U.S., Mexico and South American countries) would be a welcome development and one through which a variety of views and approaches could be exchanged. I hope that Plato will be a point of contact and a stimulus for our shared philosophical investigations and for true dialogue between different peoples.

\section{NOBURU NOTOMI}

Kyushu University.

Japan

bibiographie

FuJISAWA, N., 'Echein, Metechein, and Idioms of "Paradeigmatism" in Plato's Theory of Forms', Phronesis 19 (1974), $30-58$.

Kanayama, Y., 'Perceiving, Considering, and Attaining Being (Theaetetus 184-186),' Oxford Studies in Ancient Philosophy 5 (1987), 29-81.

KATo, S., Plato's Earlier Philosophy, (in Japanese) Tokyo, 1988.

Kato, S., 'The Apology: the Beginning of Plato's own Philosophy', Classical Quarterly NS 41 (1991), 356-64.

Kato, S., 'The Role of Paradeigma in the Statesman', in C. J. RowE, ed., Reading the Statesman: Proceedings of the III Symposium Platonicum, Saint Augustin, 1995, 162-72.

Kato, S., 'The Crito-Socrates Scenes in the Euthydemus: a Point of View for Reading the Euthydemus', in Proceedings of the V Symposium Platonicum, edd. T. M. RoBInSONand L. BRISSON, Saint Augustin, 2000, 123-32.

Matsunaga, Y., Knowing and Not-Knowing: an Introduction to the Study of Plato's Philosophy, (in Japanese) Tokyo, 1993.

Mishima, T., 'Courage and Moderation in the Statesman', in Reading the Statesman: Proceedings of the III Symposium Platonicum, ed. C. J. Rowe, Saint Augustin 1995, 306-12.

Nотомi, N., The Unity of Plato's Sophist: between the Sophist and the Philosopher, Cambridge University Press, 1999.

Notomi, N., 'Critias and the Origin of Plato's Political Philosophy', in Proceedings of the V Symposium Platonicum, edd. T. M. RoBINSON and L. BRISSON, Saint Augustin, 2000, 237-50.

Watanabe, K., 'The Theaetetus on Letters and Knowledge', Phronesis 32 (1987), 143-65. 